\title{
Electrical burns and complications: Data of a tertiary burn center intensive care unit
}

\author{
(1) Abdulkadir Başaran, M.D., 다) Kayhan Gürbüz, M.D., 들 Özer Özlü, M.D., \\ (1) Mete Demir, M.D., () Orhan Eroğlu, M.D., 다 Koray Daş, M.D.
}

Department of General Surgery, Adana City Training and Research Hospital, Burn Center, Adana-Turkey

\begin{abstract}
BACKGROUND: To review the records of electrical burn patients hospitalized in our burn intensive care unit (ICU) and to report the complications together with our treatment results.

METHODS: Demographic data, burn mechanism, presentation, percentage of burn total body surface area (TBSA), abbreviated burn severity index (ABSI) scores, complications and treatment approaches of electrical burn patients admitted to our burn ICU between September 2017 and August 2018 were evaluated retrospectively in this study.

RESULTS: Electrical burn injury patients consisted of $17.9 \%$ of the patients who were hospitalized in burn ICU ( $n=\mid 39)$. All patients were male, and the median age was 27.0 years. Twenty-three patients $(\mathbf{9 2} \%)$ were burned with high voltage electricity. The median percentage of burn TBSA score was 20.0. Eight patients had an accompanying head, a vertebra or extremity injuries. Sixteen patients $(64 \%)$ were injured at work. Sixteen patients $(64 \%)$ recovered with complications. ICU stay and total hospital stay were significantly higher in the group that healed with complications $(p=0.005$ and $p=0.001$, respectively). However, no significant differences were detected in burn TBSA and ABSI scores. TBSA and ABSI scores were correlated with ICU and total hospital stay.
\end{abstract}

CONCLUSION: The proportion of our electrical burn patients is higher than reported in the literature. Burn TBSA and ABSI scores seem unrelated to prognosis. As the majority of patients are burned with high-voltage electricity at work, these injuries can be reduced by following occupational safety principles. Because of the high rate of complications in electrical burns, an experienced health team in well-equipped centers should treat patients in accordance with updated guidelines.

Keywords: Burn; complications; electrical injury.

\section{INTRODUCTION}

Electrical burns and burn-related mortality are increasing due to the use of electricity in all areas of life and technology. Electricity-related injuries are known for their destructive complications and prolonged socioeconomic effects resulting in high morbidity and mortality in all age groups. ${ }^{[1]}$

Electrical injuries represent $4 \%$ of the patients admitted to burn centers and are more common in males. ${ }^{[2-7]}$ Electricity may cause external burns with flash injury, while internal burns can be seen by electricity warming the bone and burning the muscle nearby. Electrical injuries are classified as injuries due to low voltage $(<1000 \mathrm{~V})$ and high voltage $(>1000 \mathrm{~V})$. Thirtyseven percent of electrical injuries arises from low voltage and $63 \%$ by high voltage. ${ }^{[8]}$ Low-voltage injuries are usually more common in domestic settings and children, while adult injuries usually occur at workplaces. ${ }^{[9-12]}$ One-third of electrical injuries and most of the high-voltage injuries are related to work. More than $50 \%$ of the work-related injuries arise from the contact with the power line and are in the $4^{\text {th }}$ rank among the causes of death due to work accidents. ${ }^{[13,14]}$

Electric burns have three potential injury types as follows: electric damage due to flow, injury from electric arc passing from the electric source to an object and flame damage due to igni-

Cite this article as: Başaran A, Gürbüz K, Özlü Ö, Demir M, Eroğlu O, Daş K. Electrical burns and complications: Data of a tertiary burn center intensive care unit. Ulus Travma Acil Cerrahi Derg 2020;26:222-226.

Address for correspondence: Abdulkadir Başaran, M.D.

Adana Şehir Eğitim ve Araştırma Hastanesi, Genel Cerrahi Kliniği, Yanık Merkezi, Adana, Turkey

Tel: +90 322 - 4559000 E-mail: adkbasar@yahoo.com

Ulus Travma Acil Cerrahi Derg 2020;26(2):222-226 DOI: 10.14744/tjtes.2019.65780 Submitted: 17.12.2018 Accepted: 08.05.2019 Online: 24.02.2020

Copyright 2020 Turkish Association of Trauma and Emergency Surgery 
tion of clothing or surrounding area. In high-voltage injuries, it is not necessary to contact with the electrical current directly. The wrist and ankle are the most affected parts, whereas the severity of injury decreases proximally. Macroscopic and microscopic vascular injuries may occur immediately and are often irreversible. ${ }^{[15-18]}$ Electrical exposure may also cause cardiac arrhythmias and serious injuries to other organ systems. ${ }^{[2,19]}$

Tissue resistance against electricity decreases with bone, fat, tendon, skin, muscle, vein, and nerve order. Bone warms up to high temperatures and burns surrounding structures like muscles, which leads to muscular edema and compartment syndrome in high-voltage electrical injuries. The entry and exit wounds should be carefully assessed to determine which extremities should be closely monitored for compartment syndrome. ${ }^{[2,20]}$

Because of the different characteristics of electrical burns, in this study, we aimed to analyze retrospectively the data of electrical burn patients admitted to the burn intensive care unit (ICU) and compare our data with the current literature.

\section{MATERIALS AND METHODS}

This study was conducted at the Burn Center of Adana City Training and Research Hospital between September 2017 and August 2018. The local Clinical Research Ethical Committee of the Adana City Training and Research Hospital approved the study (Decision no: 279).

The patients admitted to our emergency department or referred from another hospital with an electrical burn diagnosis were evaluated in this study. After the first intervention and evaluation, the patients who were hospitalized to our burn ICU were included in this study.

Initial interventions were made at the emergency unit of the hospital where the patients were first admitted. X-rays, MR/ CT imaging, abdominal USG, Doppler USG examinations, electrocardiography and cardiac enzyme levels to determine arrhythmias and other cardiac injuries, as well as routine laboratory tests, were conducted. Patients were admitted to the burn ICU after consultations such as cardiology, orthopedics, neurosurgery, general surgery, thoracic surgery, and anesthesiology were done, if needed. Patients' burn TBSA and Abbreviated Burn Severity Index (ABSI) scores were recorded. The $A B S I$ is a five-variable scale to help assess burn severity and predict the probability of survival. The variables are sex, age, presence of inhalation injury, presence of a full-thickness burn, and percentage of total body surface area burned. Higher ABSI scores correspond to a lower probability of survival. ${ }^{[21]}$

The burn wounds were closed with appropriate dressings after performing escharotomy, fasciotomy, debridement and grafting depending on the condition of the burned area in the surgery room of our burn center.
After completing the treatments in the burn ICU, the patients were transferred to the burn ward and their treatment was continued there. The wounds of all patients were photographed before and after the interventions. Debridement procedures, escharotomy, fasciotomy, amputations and reconstructive procedures were all recorded. These patients were followed up later in the rehabilitation phase.

\section{Statistical Analysis}

Statistical Package for Social Sciences 20.0 for Windows was used for the analysis of the data. The normal distribution of the variables was checked with normality tests. Since the data were not distributed normally, the Mann-Whitney $U$ test was used for the analysis of continuous variables. Correlations between the variables were assessed using the Spearman rank correlation test. The results were expressed as median (interquartile range, QI-Q3), $\mathrm{n}$ and percent (\%). The values of $\mathrm{p}<0.05$ were considered as statistically significant.

\section{RESULTS}

A total of 444 patients were admitted to our burn center between September 2017 and August 2018. Among these patients, 39 (8.8\%) were electrical burns. Of the 139 patients hospitalized at our Burn Center ICU, 25 (I7.9\%) were electrical burns. All patients were male, and the median age was 27.0 (18). In 23 patients (92\%), the injury arose from high voltage and in two patients (8\%) by low voltage. The electrical injury occurred outdoors in 22 patients (88\%), and in three patients (12\%) indoors. Ten patients (40\%) had a history of falling during the injury. The percentage of burn TBSA in our patients was $20.0(6.5-44.5)$ and the ABSI score was 5.0 (5.0-7.5). The length of burn ICU stay was I0.0 (4.5-20.0) days, and the length of hospital stay was 38.0 (12.5-58.0) days And $64 \%$ of our patients were workers (five electricians, five painters, six construction worker), $24 \%$ were children $(n=6)$ and $12 \%(n=3)$ were of other occupational groups. The demographic and clinical data of our patients are given in Table I. In 21 of the patients (84\%), the entry was the upper extremity or scalp. Four patients (16\%) had a flash injury. In 17 of the 21 patients who had an entry site, the electrical exit was from inferior limbs, and no electrical exit was detected in four patients. Fifteen patients (60\%) had no additional injuries. Head trauma was present in six patients $(24 \%)$, vertebra injury in one patient $(4 \%)$, and fracture in the lower extremity in one patient $(4 \%)$ and inhalation burn in two patients (8\%).

Nine patients (36\%) were hospitalized from our hospital's emergency department, while the others were referrals from secondary $(n=12)$ and tertiary $(n=4)$ care hospitals. Fasciotomy $(n=3,12 \%)$, escharotomy $(n=9,36 \%)$, debridement $(n=13,52 \%)$ and grafting $(n=11,44 \%)$ were the first intervention procedures. Patients were followed by these interventions depending on the wound. Vacuum-assisted closure was applied when needed. Amputation was performed in patients 
when complete demarcation observed $(n=5,14$ finger amputations, one transtibial amputation). Following amputations, defects were closed primarily or by grafting where necessary.

During hospitalization, consultations from the Departments of Orthopedics, Plastic and Reconstructive Surgery and Neurosurgery were requested according to the injured body part and severity of the injury. Also, physical therapy and rehabilitation methods were applied to the patients.

Table I. Demographic and clinical data of our patients

\begin{tabular}{lc}
\hline & Median (QI-Q3) \\
\hline Age (years) & $27.0(17.5-35.5)$ \\
Gender (M/W)* & $25 / 0$ \\
Profession (Worker/Other)* & $16 / 9$ \\
Cause of injury (High/Low voltage)* & $23 / 2$ \\
Injury place (Outdoor/lndoor) & $22 / 3$ \\
Burn TBSA (\%) & $20.0(6.5-44.5)$ \\
ABSI score & $5.0(5.0-7.5)$ \\
ICU stay (day) & $10.0(4.5-20.0)$ \\
Total hospital stay (day) & $38.0($ I2.5-58.0) \\
\hline "The data are given as number (n). TBSA: Total body surface area; ABSI: Abbre- \\
viated burn severity index; ICU: Intensive care unit.
\end{tabular}

Table 2. Correlation between burn TBSA, ABSI score, intensive care stay and total hospital stay

\begin{tabular}{lccc}
\hline & Burn TBSA & ICU stay & Total hospital stay \\
\hline ABSI score & 0.918 & 0.690 & 0.558 \\
& 0.000 & 0.000 & 0.009 \\
Burn TBSA & & 0.775 & 0.628 \\
& & 0.000 & 0.002 \\
Intensive care stay & & & 0.762 \\
& & & 0.000 \\
\hline
\end{tabular}

TBSA: Total body surface area; ABSI: Abbreviated burn severity index; ICU: Intensive care unit. [In the rows, $r$ values (correlation coefficient) are in the first and $p$ values are in the second order].
Nine of our patients (36\%) recovered without complications. Sixteen $(64 \%)$ of the patients developed one or more complications: One patient developed an incomplete tetraplegia due to fall during electrical injury, nine patients developed contracture of joints, nine patients had sepsis, three patients had median nerve damage due to injury at wrist and five patients developed necrosis requiring amputation of total 14 fingers. One of these patients later underwent transtibial amputation. One patient with accompanying inhalation burn (TBSA $=64 \%$ ) died on day 14 .

Supraventricular tachycardia was observed in only one patient, which was treated by a single dose of the beta-blocking agent. No other cardiac event was detected.

When we analyzed the correlations between TBSA, ABSI score, ICU stay and total hospital stay, moderate-good correlations were detected between these variables $(r>0.50)$ (Table 2), which means the higher the scores, the longer the ICU and total hospital stay.

We further analyzed our data according to the subgroups "healing without complication" and "healing with complication." No significant differences were detected concerning age, TBSA and ABSI scores $(p=0.10, p=0.06$ and $p=0.07$, respectively) between these groups. However, the duration of ICU stay and total hospital stay were significantly higher in the group healing with complications $(p=0.005$ and $p=0.00$ I, respectively) (Table 3 ).

\section{DISCUSSION}

Electrical burns are quite different from thermal and chemical burns. The severity of the electrical injury depends on many factors, such as the voltage, duration of contact, tissue resistance, skin moisture, and the presence of flash components and the ignition of clothing. Most of these injuries among adults are due to high voltage electric lines. ${ }^{[13,15]}$

Electrical injuries account for up to $4 \%$ of the patients hospitalized in burn centers. ${ }^{[2]}$ Albayrak et al. ${ }^{[22]}$ stated, in their retrospective study, that $5.3 \%$ of the patients who were hospitalized in the burn center for eight years were electrical burns. Brandão et al. ${ }^{[23]}$ reported this rate as $5.84 \%$ in the patients they followed for 10 years.

Table 3. Comparison of groups healing without or with complication

\begin{tabular}{lccc}
\hline & $\begin{array}{c}\text { Without complication }(\mathbf{n}=9) \\
\text { Median (QI-Q3) }\end{array}$ & $\begin{array}{c}\text { With complication }(\mathbf{n}=16) \\
\text { Median }(\mathbf{Q} I-\mathbf{Q})\end{array}$ \\
\hline Age (years) & $19.0(16.5-31.0)$ & $28.5(21.0-40.25)$ & $\mathbf{p}$ \\
Burn total body surface area (\%) & $7.0(4.5-29.0)$ & $28.5(12.0-52.5)$ & 0.10 \\
Abbreviated Burn Severity Index score (n) & $5.0(3.5-5.5)$ & $6.0(5.0-8.75)$ & 0.06 \\
Intensive care unit stay (day) & $5.0(3.5-7.5)$ & $15.5(8.5-30.5)$ & 0.07 \\
Total hospital stay (day) & $14.0(8.0-20.0)$ & $51.5(38.0-70.5)$ & 0.005 \\
\hline
\end{tabular}


In the current study, the rate of electrical burns among the patients who were hospitalized in our burn center was $8.8 \%$. This rate is considered to be higher than that reported in the literature since we serve as a tertiary burn center and $64 \%$ of our patients were referred from secondary and tertiary care hospitals. For the same reason, the high voltage electrical injury rate was higher in our patients (92\%).

Aghakhani et al. ${ }^{[24]}$ examined the effects of current pathways on the mortality and morbidity in electrical burns and determined seven different groups according to the entry and exit points of the current. The authors concluded that the most common entry-exit sites were right upper-left lower extremities and the morbidities, such as mortality and amputation were not different between these pathways. Similarly, in our patients, the most frequent entry-exit pathway was the upper-lower extremity.

In the literature, different data have been reported regarding the complications seen in electrical burns and the proportions of these complications. ${ }^{[22,23,25-27]}$

Li et al. ${ }^{[27]}$ analyzed the data of 82 patients who underwent amputation among the patients they followed for 12 years and reported that $51.2 \%$ of them were due to electrical burns. Zikaj et al. ${ }^{[25]}$ reported a $40.7 \%$ amputation and $12.1 \%$ cardiorespiratory distress rate in 31 patients they followed between 2015 and 2017. The amputation rate was $20 \%$ in our patient group during the one-year study period. Only one of the patients who was monitored during ICU hospitalization had a short-term ventricular tachycardia and no serious cardiac event was observed in our study. Although it is not statistically significant, Brandão et al. ${ }^{[23]}$ found the amputation rate $(16.7 \%)$ higher in the high voltage electrical burn group in their study. Since $92 \%$ of our patients were high-voltage electrical burns, no such sub-analysis was performed.

Kurt et al. ${ }^{[26]}$ reported the infection rate as $32.9 \%$ in 94 patients they followed for four years. Similarly, the infection rate was $36 \%$ in our study. Cancio et al. ${ }^{[3]}$ stated that there is no index available for electrical injury, analogous to burn size for the thermal injury that allows one to quantify the severity of the injury. Li et al. ${ }^{[28]}$ analyzed the wound treatment data in 595 patients with electrical burns between 2013 and 2015. They found that high-voltage electrical current injuries and the number of operations performed per patient were major risk factors for hospital stay and amputations. The duration of ICU and total hospital stay was found to be significantly longer in the group that healed with complications (including amputations) in our study. However, as the TBSA and ABSI scores were not significantly higher in the group healing with complications, we can comment that these scores are not useful for predicting prognosis in electrical burn injuries, as also stated by Cancio et al. ${ }^{[3]}$
The relatively small number of patients and the limited follow-up data together with shortness of our follow-up time can be listed among the limitations of our study.

In conclusion, electrical burns differ from other burns concerning mechanism, presentation, morbidity, complications and treatment strategies. The surgical management of electrical burns is characterized by early debridement. Appropriate skin grafts or myocutaneous pedicle flaps are used for repairing tissue defects. Amputations should be avoided until the demarcation line is settled completely.

Although the percentage of electrical burns is lower among all burn patients, the rate of admission to ICU is higher. In addition, the TBSA and ABSI scores used in predicting the prognosis in burn patients are not directly related to the prognosis in electrical burns. The majority of our patients were adult males injured by a high voltage at work. Therefore, compliance with occupational safety principles and regular monitoring of electrical networks may reduce injuries. These patients should be addressed in well-equipped centers in accordance with experienced team members and updated guidelines.

Ethics Committee Approval: Approved by the local ethics committee.

Peer-review: Internally peer-reviewed.

Authorship Contributions: Concept: A.B., K.G., Ö.Ö., K.D.; Design: A.B., K.G., Ö.Ö., M.D.; Supervision: Ö.Ö., M.D., O.E., K.D.; Materials: A.B., K.G., Ö.Ö.; Data: A.B., K.G., Ö.Ö., M.D., O.E.; Analysis: A.B., K.D.; Literature search: A.B., K.G.; Writing: A.B., K.G., K.D.; Critical revision: K.G., Ö.Ö., K.D.

Conflict of Interest: None declared.

Financial Disclosure: The autors declared that this study has received no financial support.

\section{REFERENCES}

1. Arnoldo BD, Purdue GF, Kowalske K, Helm PA, Burris A, Hunt JL. Electrical injuries: a 20-year review. J Burn Care Rehabil 2004;25:479-84.

2. Friedstat J, Brown DA, Levi B. Chemical, Electrical, and Radiation Injuries. Clin Plast Surg 2017;44:657-69. [CrossRef]

3. Cancio LC, Jimenez-Reyna JF, Barillo DJ, Walker SC, McManus AT, Vaughan GM. One hundred ninety-five cases of high-voltage electric injury. J Burn Care Rehabil 2005;26:331-40. [CrossRef]

4. Kopp J, Loos B, Spilker G, Horch RE. Correlation between serum creatinine kinase levels and extent of muscle damage in electrical burns. Burns 2004;30:680-83. [CrossRef]

5. Luz DP, Millan LS, Alessi MS, Uguetto WF, Paggiaro A, Gomez DS, et al. Electrical burns: a retrospective analysis across a 5-year period. Burns 2009;35:1015-9. [CrossRef]

6. Ferreiro I, Meléndez J, Regalado J, Béjar FJ, Gabilondo FJ. Factors influencing the sequelae of high tension electrical injuries. Burns 1998;24:649-53. [CrossRef]

7. Hussmann J, Kucan JO, Russell RC, Bradley T, Zamboni WA. Electrical injuries--morbidity, outcome and treatment rationale. Burns 
1995;21:530-5. [CrossRef]

8. Rai J, Jeschke MG, Barrow RE, Herndon DN. Electrical injuries: a 30year review. J Trauma 1999;46:933-6. [CrossRef]

9. Farooq U, Ahmed I, Maryum A. Electric burn injuries. Rawal Med J 2010;35:137-40.

10. Cheema SA. Pattern and profile of electric burn injury cases at a Burn centre. J Ayub Med Coll Abbottabad 2016;28:702-5.

11. Muqim R, Zareen M, Dilbag, Hayat M, Khan MI. Epidemiology and outcome of Burns at Khyber Teaching Hospital Peshawar. Pak J Med Sci 2007;23:420-4.

12. Khan N, Malik MA. Presentation of burn injuries and their management outcome. J Pak Med Assoc 2006;56:394-7.

13. Varghese G, Mani MM, Redford JB. Spinal cord injuries following electrical accidents. Paraplegia 1986;24:159-66. [CrossRef]

14. Martinez JA, Nguyen T. Electrical injuries. South Med J 2000;93:11658. [CrossRef]

15. VanDenburg S, McCormick GM 2nd, Young DB. Investigation of deaths related to electrical injury. South Med J 1996;89:869-72. [CrossRef]

16. Bernal E, Arnoldo BD. Electrical Injuries. In: Herndon DN, ed. Total Burn Care. 5th edition. Galveston, TX: Elsevier; 2018. p. 396-402e2.

17. Talbot SG, Upton J, Driscoll DN. Changing trends in pediatric upper extremity electrical burns. Hand (N Y) 2011;6:394-8. [CrossRef]

18. Zelt RG, Daniel RK, Ballard PA, Brissette Y, Heroux P. High-voltage electrical injury: chronic wound evolution. Plast Reconstr Surg 1988;82:1027-41. [CrossRef]

19. Purdue GF, Hunt JL. Electrocardiographic monitoring after electrical injury: necessity or luxury. J Trauma 1986;26:166-7. [CrossRef]
20. Piccolo NS, Piccolo MS, Piccolo PD, Piccolo-Daher R, Piccolo ND, Piccolo MT. Escharotomies, fasciotomies and carpal tunnel release in burn patients--review of the literature and presentation of an algorithm for surgical decision making. Handchir Mikrochir Plast Chir 2007;39:161-7.

21. Dahal P, Ghimire S, Maharjan NK, Rai SM. Prediction of outcome of acute burn injury by Baux's and abbreviated burn severity index score. JCMS Nepal 2015;11:24-7. [CrossRef]

22. Albayrak Y, Temiz A, Albayrak A, Peksöz R, Albayrak F, Tanrıkulu Y. A retrospective analysis of 2713 hospitalized burn patients in a burns center in Turkey. Ulus Travma Acil Cerrahi Derg 2018;24:25-30. [CrossRef]

23. Brandão C, Vaz M, Brito IM, Ferreira B, Meireles R, Ramos S, et al. Electrical burns: a retrospective analysis over a 10-year period. Ann Burns Fire Disasters 2017;30:268-71. [CrossRef]

24. Aghakhani K, Heidari M, Tabatabaee SM, Abdolkarimi L. Effect of current pathway on mortality and morbidity in electrical burn patients. Burns 2015;41:172-6. [CrossRef]

25. Zikaj G, Xhepa G, Belba G, Kola N, Isaraj S. Electrical Burns and Their Treatment in a Tertiary Hospital in Albania. Open Access Maced J Med Sci 2018;6:835-8. [CrossRef]

26. Kurt A, Yildırım K, Yağmur Ç, Kelahmetoğlu O, Aslan O, Gümüş M, et al. Electrical burns: Highlights from a 5-year retrospective analysis. Ulus Travma Acil Cerrahi Derg 2016;22:278-82.

27. Li Q, Wang LF, Chen Q, Wang SJ, Li F, Ba T. Amputations in the burn unit: A retrospective analysis of 82 patients across 12 years. Burns 2017;43:1449-54. [CrossRef]

28. Li H, Tan J, Zhou J, Yuan Z, Zhang J, Peng Y, et al. Wound management and outcome of 595 electrical burns in a major burn center. J Surg Res 2017;214:182-9. [CrossRef]

\section{ORİJINAL ÇALIŞMA - ÖZET}

\section{Elektrik yanıkları ve komplikasyonları: Üçüncü basamak yanık merkezi yoğun bakım ünitesi verileri}

\section{Dr. Abdulkadir Başaran, Dr. Kayhan Gürbüz, Dr. Özer Özlü, Dr. Mete Demir, Dr. Orhan Eroğlu, Dr. Koray Daş}

Adana Şehir Eğitim ve Araştırma Hastanesi, Genel Cerrahi Kliniği, Yanık Merkezi, Adana

AMAÇ: Yanık merkezi yoğun bakım ünitemizde tedavi edilen elektrik yanıklı hastaların verilerini gözden geçirerek tedavi sonuçlarımız ile birlikte komplikasyonları tartışmak amaçlanmıştır.

GEREÇ VE YÖNTEM: Eylül 20।7-Ağustos 2018 tarihleri arasında yanık merkezi yoğun bakım ünitesinde yatan elektrik yanıklı hastaların demografik verileri, yanık mekanizması, prezentasyonu, ortalama yanık total vücut alanı yüzdesi (TBSA), kısaltılmış yanık şiddeti indeksi (ABSı) skorları, komplikasyonlar ve tedavi yaklaşımları geriye dönük olarak incelendi.

BULGULAR: Yanık merkezi yoğun bakım ünitemize yatırılan hastaların ( $n=139)$ \% I 7.9'u elektrik yanığı hastası idi. Hastaların tümü erkekti ve ortanca yaşları 27.0 yıl idi. Hastaların 23’ü yüksek voltaj (\%92), ikisi düşük voltaj (\%8) elektrik ile yanmıştı. Ortanca yanık TBSA skoru 20.0 idi. Sekiz hastada eşlik eden baş, vertebra veya ekstremite yaralanmaları mevcuttu. Hastaların I6'sı (\%64) işte yaralanmıştı. On altı hasta (\%64) komplikasyonla iyileşti. Komplikasyonla iyileşen grupta yoğun bakım ve toplam hastane kalış süreleri istatistiksel olarak anlamlı derecede yüksekti (sırasıyla, $\mathrm{p}=0.005$ ve $p=0.001$ ), ancak TBSA ve ABSI skorlarında anlamlı farklılık görülmedi. TBSA ve ABSI skorları yoğun bakım ve toplam hastane yatış süreleri ile korele bulundu.

TARTIŞMA: Elektrik yanıklı hastalarımızın yüzdesi literatürde belirtilenden yüksektir. Yanık TBSA ve ABSı skorlarının prognozla ilişkili olmadığı görülmüştür. Elektrik yanıklı hastaların çoğunluğu iş kazasında yüksek voltajla yaralandığından, iş güvenliği ilkelerine uyulması bu yaralanmaları azaltabilir. Elektrik yanıklarında komplikasyon oranı yüksek olduğundan hastaların deneyimli sağlık ekibi eşliğinde, tam donanımlı merkezlerde, güncel rehberlere göre tedavisi yapılmalıdır.

Anahtar sözcükler: Elektrik yaralanması; komplikasyonlar; yanık.

Ulus Travma Acil Cerrahi Derg 2020;26(2):222-226 doi: 10.14744/tjtes.2019.65780 